\title{
A COMPARISON BETWEEN OPTICAL AND RADAR SATELLITE IMAGES FOR DETECTING TROPICAL FOREST FIRES IN SOUTH SUMATRA, INDONESIA
}

\author{
by: \\ Heri Sunuprapto ${ }^{1}$ and Yousif Ali Hussin ${ }^{2}$ \\ ${ }^{1}$ Ministry of Forestry - Manggala Wanabakti - \\ Jl. Gatot Subroto Jakarta 10076, Indonesia, \\ sunuprapto@gmail.com \\ ${ }^{2}$ The International Institute for Aerospace Survey and \\ Earth Science (ITC) 7500 AA, Enschede, The Netherlands \\ Fax (31)53-4874-399 \\ Hussin@ITC.NL
}

\begin{abstract}
Forest fire in Indonesia is a yearly potential caused for forest degradation. The information available about the main factors that promote the forest fire and information about the forest condition after the forest fire are insufficient. This is one of the reasons why forest area neglected after they are burned. Remote sensing and GIS are helpful tools to provide a quick and accurate data acquisition and that can describe the forest condition after the forest fire. The objectives of this research were to asses the ability of optical and radar satellite remotely sensed data to detect, identify and classify forest damage (burnt area) caused by fire and to develop a spatial model for forest fire hazard.
\end{abstract}

Key words: detection burnt forest, Landsat-TM, ERS, and JERS images.

\section{PERBANDINGAN ANTARA CITRA SATELIT OPTIK DAN RADAR DALAM MENDETEKSI KEBAKARAN HUTAN TROPIS DI SUMATRA SELATAN, INDONESIA}

\begin{abstract}
Abstrak
Kebakaran hutan di Indonesia merupakan potensi tahunan yang disebabkan oleh degradasi hutan. Informasi yang tersedia tentang faktor utama yang mempromosikan kebakaran hutan dan informasi tentang kondisi hutan setelah kebakaran hutan tidak cukup. Ini adalah saah satu alasan mengapa kawasan hutan diabaikan setelah dibakar. Penginderaan jauh dan SIG merupakan alat untuk membantu memberikan akuisisi data yang cepat dan akurat yang dapat menggambarkan kondisi hutan setelah kebakaran hutan. Tujuan dari penelitian ini adalah untuk menilai kemampuan satelit optik dan radar. Data penginderaan jauh untuk mendeteksi, mengidentifikasi, dan mengklasifikasi kerusakan hutan (kawasan yang terbakar) yang disebabkan oleh kebakaran dan untuk menggambarkan model spasial untuk bahaya kebakaran hutan.
\end{abstract}

Kata kunci: deteksi kebakaran hutan, Citra Landsat-TM, ERS, dan JERS. 


\section{Introduction}

Forest is one of the most important renewable natural resources and has significant role in the human life and environment. Forest not only produce wood, both commercial timber and fuel wood, but they also protect wildlife and give them suitable environment, maintain the watershed balance and groundwater content, protect the soil fertility, and absorb carbon and another pollutant gasses from the atmosphere. All of these forest functions influence to the continuity of life and has a global aspect.

Due to natural causes and human activity forest has been degrading, both forest area degradation and forest condition and quality. Forest area decreased in huge number annually. Forest quality degrade on its productivity, degrade in biodiversity, degrade on its capability to fulfil the forest function. One of the main cause that responsible to forest degradation is forest fire.

Roughly 175 million acres of forest and grassland are burned each year world-wide. Due to large-scale human deforestation activities, grassland fires, and naturally occurring wild fires around the world, biomass burning is a major source of greenhouse gases and aerosols (tiny liquid or solid particles suspended in the atmosphere). These "emission products" significantly impact atmospheric chemistry, clouds, and the Earth's radiant energy budget (heat and sunlight) in ways that influence climate on regional and global scales. In recent months, the extensive fires in Florida, Mexico, Brazil, and Indonesia have catapulted this topic into the news headlines.

In Russia. The temporal series (fire season between 1947 and 1992) of the area affected forest fire on the Forest Fund's actively protected territory is characterised by great variability in both the number of fires and the annual area burned. The number of fires ranged from 10,000 to 34,000 annually, with the corresponding area burned varying between 200,000 and 2,700,000 hectares (Goldammer and Furyaev, 1996).

In the last two decades, fire has become one of the greatest threats to tropical rainforest, especially in Indonesia. Fire has been a recurring feature of the islands of Borneo and Sumatra, burning large areas in 1986, 1991, 1994 and 1997. Boosted by 1997/1998 El Nino phenomenon uncontrolled fires have destroyed huge areas of rain forest and bush land in Indonesia. Since the 1986 fires, Indonesia has been at odds with neighbouring Malaysia and Singapore, as the haze from these fires covered the South East Asian region for weeks, causing health problems, disruption of shipping and aviation, and culminating in the closure of international airports. Economic losses and ecological damage were enormous.

The recent fire disaster in Indonesia shows the need for a forest fire monitoring and damaged assessment. The activities should be done in order to provide a reliable and up to date information about the recent forest cover area and its quality to support forest management purposes.

In considering the applications of remote sensing, foresters and geologist have been the main operational users of the collected data for many years. Sometimes the remote sensing system provides unique data that cannot be obtained by any others source; but much more often that collected data facilitates field work and enables task to 
be completed at lower cost and much more quickly. It is unlikely, these days, that forest inventory would be undertaken without remotely sensed data. Usually field collected data provides more accurate and precise result, but the collection of the data is slow. In rugged terrain, it may be economically impracticable or confined only to a few ground samples in accessible locations. Ensuing from this the common forest practise of marrying remotely sensed data and field data and cross-checking continuously the result of image analysis and field samples.

Due to the difficulty of monitoring burned forest areas and the absence of detailed fire records in many areas, the possibility of using remote sensing satellite observations will be examined. Moreover, the inaccessible large forest areas should be monitored by employing remote sensing data.

Some remote sensing techniques and data can be used for the detection of forest fire and the assessment of their affects. The application of the forms of the remote sensing depends on the character of forest management. The multi-spectral scanner data from the aerial and satellite platform can be used in the extensive management of great areas. Attention has been drawn to the fact that the detection of damaged caused by fires may concern large areas only.

In recent time radar system has a significant role in remote sensing since there are some limitation with optical remote sensing system like cloud cover penetration capability. Radar data which utilizes the microwave portion of the spectrum can provide important additional information of terrain surface and vegetation canopies (Stellingwerf and Hussin, 1997).

The objectives of this research were to asses the ability of optical and radar satellite remotely sensed data to detect, identify and classify forest damage (burnt area) caused by fire and to develop a spatial model for forest fire hazard.

\section{Method}

In order to investigate the effect of forest fire and to asses the ability of remote sensing data to detect, differentiate and classify forest damaged caused by fire, remotely sensed data and image processing techniques were employed. Data and basic methodology can be seen in Figure 1. 
A Comparison Between Optical and Radar Satellite Images For Detecting Tropical Forest Fires in South Sumatra, Indonesia

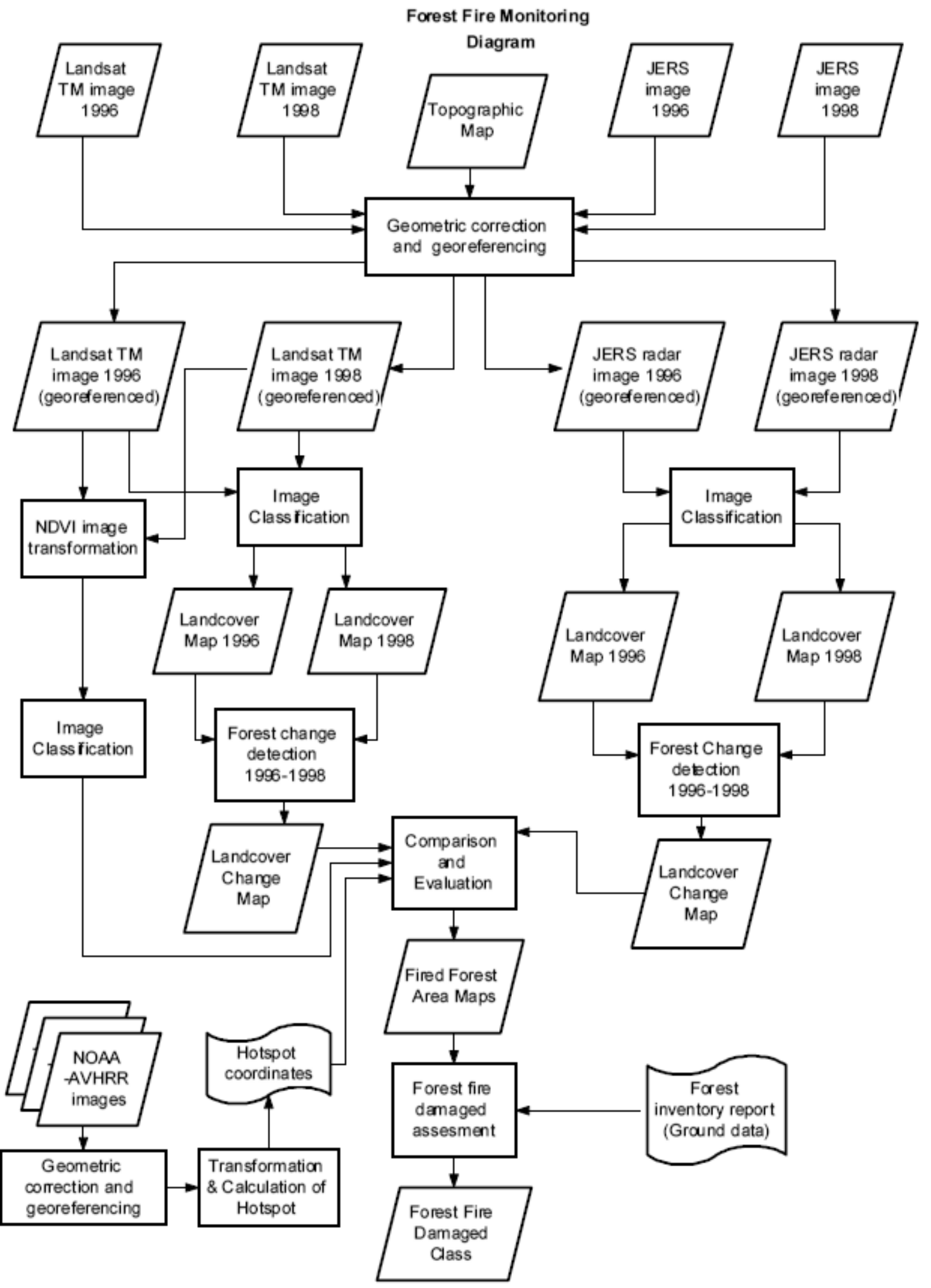




\section{Study Area}

Geographically the study area is located between longitude $105^{\circ} 14^{\prime} 36^{\prime \prime}$ East and $105^{\circ} 38^{\prime} 45^{\prime \prime}$ East and between latitude $2^{\circ} 38^{\prime} 38^{\prime \prime}$ South and $2^{\circ} 54^{\prime} 05^{\prime \prime}$ South, lies in South Sumatra Province (Propinsi Sumatera Selatan), Lower Ogan Komering District (Kabupaten Ogan Komering Ilir), in eastern part of Sumatra island, Indonesia. The study area covers about $55 \mathrm{~km} \times 30 \mathrm{~km}(1650 \mathrm{~km} 2)$.

The study area is part of the three forest concession companies (HPH) adjacent each others, they are PT. Sri Bunian as biggest part of the study area, followed by PT. Inhutani V (ex. PT. Sinar Belanti), and PT. SBA Wood Industries. In the west of study area neighbours Sugihan Kanan Transmigration area. These three forest concession company have been selectively logged the study area for many years. Refer to The Forest Land use Planning map (TGHK) the forest status of the study area is classified into four classes: Protection Forest $(\mathrm{HL})$, Production Forest $(\mathrm{HP})$, Convertible Forest (HPK) and Natural Forest Reserve and Tourism (HAS-W). All the classification above are only on the map the reality might be not exactly same as those above classification. The present land use of the Convertible Forest is agriculture land and settlements of Sugihan Kanan transmigration area.

Water transportation is the only way to reach the study area. Sugihan river continued by Beyuku river is the normal route to reach the western part of the study area. This route connected the western part of the study area to nearest city (Palembang) around $100 \mathrm{~km}$ away, by river transportation (small speed boat) and take 2-3 hours. While to reach the eastern part of the study area longer route including sea boating through the Bangka strait should be taken, finally the route end in the estuary of Batang river and it take 6-7 hours by speed boat.

\section{Forest Covers}

The study area is mainly peat swamp forest ecosystem. Peat is a soil type with a very high organic content. Certain international agriculture-oriented criteria now define peat as a soil with more than $30 \%$ organic matter but peat swamp forest do not develop on such soils. The peat swamp forest occurred in soil with higher organic content as a soil at least $50 \mathrm{~cm}$ deep which, when dried and burned, will lose more than $65 \%$ of its mass.

The peat forest comprises a large number of species, some of which are attractive for loggers such as 'Balam', Ramin (Gonystylus bancanus) and several dipterocarps (three species of Shorea, one species of Anisoptera). Forestry practises generally involve the use of lorry system for carriage. I most cases, the trunk are sown into small logs on the spot and dragged or pushed by workers over rolling log path to the main roads. Forest exploitation is limited to areas where peat depth is shallow and, due to high running costs, has not given rise to major operations. This is doubtlessly the reason why vast of relatively undisturbed forest can still be found today even if large zone have been put to agriculture use. But the huge fire during 1997-1998 had been burnt almost the remain of undisturbed forest (virgin forest) in the study area. 
Due to it have been observed vegetation varies according to peat depth, further the peat swamp environment divide into three different formation based on the peat layer thickness.

Mixed peat swamp forest on shallow peat layer $(<2 m)$. The stucture of this forests is similar to that of the drained lowland forests, with emerging trees ettaining height of 45 to $50 \mathrm{~m}$ and the canopy often situated thirty to thirty five meters above ground. In Southern Sumatra, the emergent tree species are Shorea uliginosa, S. Teijsmannia (Dipterocarpaceae), Dyera lowi (Apocynaceae), while those most representative of the canopy include additionally: Tetramerista glabra (Tetrameristaceae), Campnosperma coriaceum (Anarcadiceae), Mezzettia leptopoda, Xylopia fusca (Annonaceae), Durio carinatus (Bombacaceae) and Santiria laevigata f. glabrifolia (Burseraceae).

Formation on moderately thick peat layers $(2-5 \mathrm{~m})$. The height and the physiognomy of the forest diminish rapidly as one penetrates further inland, diameters tend towards homogeneity and the stem density is higher. From the floristic standpoint, the extreem abundance of callophyllum sundaicum is an excellent indications this zone boundary, where floristic diversity diminishes also notably. Pandanus atrocarpus become more rare, while Ilex cymosa starts to dominate.

Low pole forests ('padang') on deep peat layers $(>5 \mathrm{~m})$. Padang is shrubby vegetation in which the tallest trees usually only about $5 \mathrm{~m}$, but trees reaching $25 \mathrm{~m}$ are not unknown. It was reported the occurrence of the Padang vegetation in the deep peat layers but based on the ground survey done by the author in 1999 Padang vegetation could not be observed in the study area.

Secondary vegetation in peat swamp environment is not well documented. It had been observed they are most characterized, in areas where the peat is not too thick, by a shrubby vegetation composed of Combretocarpus rotundatus, Lophopetalum sp. and Campnosperma coriaceum. The latter is sometimes monodominant. On thick peat layer, Callophyllum sundaicum, Ilex cymosa, Tristaniopsis obovata and Ploiarium alternifolium dominate, while Cyperaceae remain abundant in the undergrowth.

\section{Forest Fire In The Study Area}

The recent major fires in Indonesia and elsewhere coincide with the El Nino events; and therefore has been blamed for the damage and devastation caused by these fires. $\mathrm{El}$ Nino is weather phenomenon, which aggravates the forest fire danger situation, by creating drought conditons conducive for the spread of wildfire. El Nino it self is not sufficient cause for forest fire; and major fire have taken place in Indonesia not simply due to El Nino, but due to much more complex interaction of human induced conditions, which among others, include availability of dry fuel load (caused by wasteful logging, land clearing), providing the material to feed the conflagration and an ignition source.

The summarise of recorded rainfall data of the three years monitoring by FFPCP (1996-1998) shows the anomaly of weather phenomenon (El Nino) during 1997. There was no effective rainfall in 1997 over southern Sumatra between mid-May and midNovember and this greatly exacerbated the number of serious uncontrolled fire. 
Table 1. The Monthly Rainfall During 1996-1998

\begin{tabular}{|l|l|l|l|l|l|l|l|l|l|l|l|l|}
\hline YEAR & \multicolumn{10}{|l|}{ Monthly Total (mm) } \\
\hline & JAN & FEB & MAR & APR & MAY & JUN & JUL & AUG & SEP & OCT & NOV & DEC \\
\hline 1996 & 244 & 292 & 304 & 231 & 53 & 271 & 173 & 99 & 126 & 303 & 314 & 294 \\
\hline 1997 & 139 & 292 & 319 & 336 & 215 & 65 & 6 & 4 & 0 & 6 & 124 & 330 \\
\hline 1998 & 207 & 165 & 402 & 282 & 177 & 137 & 181 & 119 & 213 & 137 & 310 & 390 \\
\hline $\begin{array}{l}8 \text { year } \\
\text { Average } \\
(1991- \\
\text { 1998) }\end{array}$ & 240 & 247 & 322 & 283 & 181 & 136 & 125 & 113 & 143 & 197 & 303 & 881 \\
\hline
\end{tabular}

Source: Palembang BMG data summarized by FFPCP

In general most of the fire result from land clearing and other agriculture practices, and are concentrated in areas of human settlement. This can be new settlement where primary or logged forest is being converted to agriculture or in areas where secondary forest and scrub is cleared for plantation shifting cultivation. Some case especially for the study area fire occurrence did not follow the general pattern described above.

In South Sumatra province fire had been appear from June 1997 with the maximum fire activity in September 1998. Smoke haze affected most of Sumatra north of Lampung, Singapore and southern peninsular Malaysia from the beginning of September until midNovember. The smoke pollution caused by the 1997 fires in Sumatra came largely from the burning of peat land in eastern coastal areas, mainly in South Sumatra province.

\section{Results And Discussions}

The peat swamp forest, where the current research is investigating the forest fire, is a unique cover type in comparison to other tropical forest. It is found mostly on flat coastal plain in a swampy location. Only in the dry season in such forest, the root level is frequently inundated. Because the soil is not solid due to accumulation of partially decomposed fallen trunks, branches and leaves, tree roots tend to be webby and spreading.

Fires in Indonesia are almost always human caused. 1996/1997 Fires did not start by accident. Most were set deliberately, and often illegally, to clear land for planting agriculture crops, to cover up illegal logging and mostly to clear logged-over forest so they can create new rubber or other forest trees plantations. They were made worse this time in part because of the century's most severe El Nino -Southern Oscillation (ENSO) weather event, which has caused drought over this region between January and May 1996, drying out the forests and make them more susceptible to fire.

The remotely sensed data used in this study were the optical Landsat Thematic Mapper images and ERS-2 and JERS-1 radar images. The preliminary result shows that it is possible to detect burnt forest using unique color combination of the optical spectral band. However ERS-2 image does show the burnt forest but not as good as the optical data. JERS-1 Radar image was able to differentiate burnt from unburnt forests. 
A Comparison Between Optical and Radar Satellite Images For Detecting Tropical Forest Fires in South Sumatra, Indonesia

Study area covers around $1299 \mathrm{~km} 2$ (image coverage) and was burnt extensively by 1997 forest fire. Satellite images data were used to extract information of the burnt area by combining the optical image capability and radar image advantages. Based on the Burnt Area map the areas affected by the fire is $640.11 \mathrm{~km} 2$ or $49 \%$ of total study area. What are left from the burnt forests are burnt trees "standing dry stems without crown" (Figure 2).

The burnt areas can be classified into four damage intensity level: low damage intensity, moderate damage intensity, high damage intensity, and extreme damage intensity. The area of each damage intensity class is:

- low damage intensity 9421.11 ha (15\% of burnt area)

- moderate damage intensity 17155.80 ha (27\% of burnt area)

- high damage intensity 33421.41 ha ( $54 \%$ of burnt area)

- extreme damage intensity 2480.22 ha ( $4 \%$ of burnt area)

Land Cover Type map of the study area derived from satellite data interpretation classified the study area into nine land cover types excluding sea and river. All of these land cover types had been burnt in certain proportion and damaged in certain intensity level. Logged over forest was burnt very extensive. The damaged area is 19138 ha and it was the largest land cover type that had been burnt. The rank will be different if we consider the proportion of the burnt area each land cover type with its total area; virgin forest is the highest proportion of the burnt area, which has been burnt $89 \%$ of its total. The lowest area and the lowest proportion burnt area is mangrove forest that was burnt only 34.02 ha or $3 \%$ of its total land cover type area.

1. Transmigration area 222.75 ha

2. Virgin forest 17195.49 ha

3. Logged over forest $\mathbf{1 9 1 3 8 . 6 8}$ ha

4. Young secondary forest 17180.91 ha

5. Savannah grassland 5904.90 ha

6. Bareland 3798.90 ha

7. Swampy area 241.38 ha

8. Nipa forest 281.88 ha

9. Mangrove forest 34.02 ha

Using Landsat TM data it is easy to differentiate the burnt area and unburnt area and in certain accuracy level can provide damage intensity information in four damage intensity level (Figure 3). The disadvantages of the optical data is their dependency to weather situation and day time.

ERS-2 SAR data and JERS SAR both are active micro wave remote sensing system which have a significant advantage by their capability to penetrate clouds cover and in some intensity also can penetrate rain. The other advantage of the active radar system is can be operating in nighttime. These two capabilities are important to complement the optical disability. ERS-2 radar data that work in C-band $(5.7 \mathrm{~cm})$ radar wavelength can be used to differentiate forest and non forest land cover type with low accuracy. Similarly the results of the use of ERS to differentiate the burnt and unburnt area was not satisfactory 
(Figure 4). JERS radar that work with L-band $(23.5 \mathrm{~cm})$ provides information of forest cover and non forest cover and also can be used to differentiate the burnt and unburnt area with good accuracy (Figure 5).

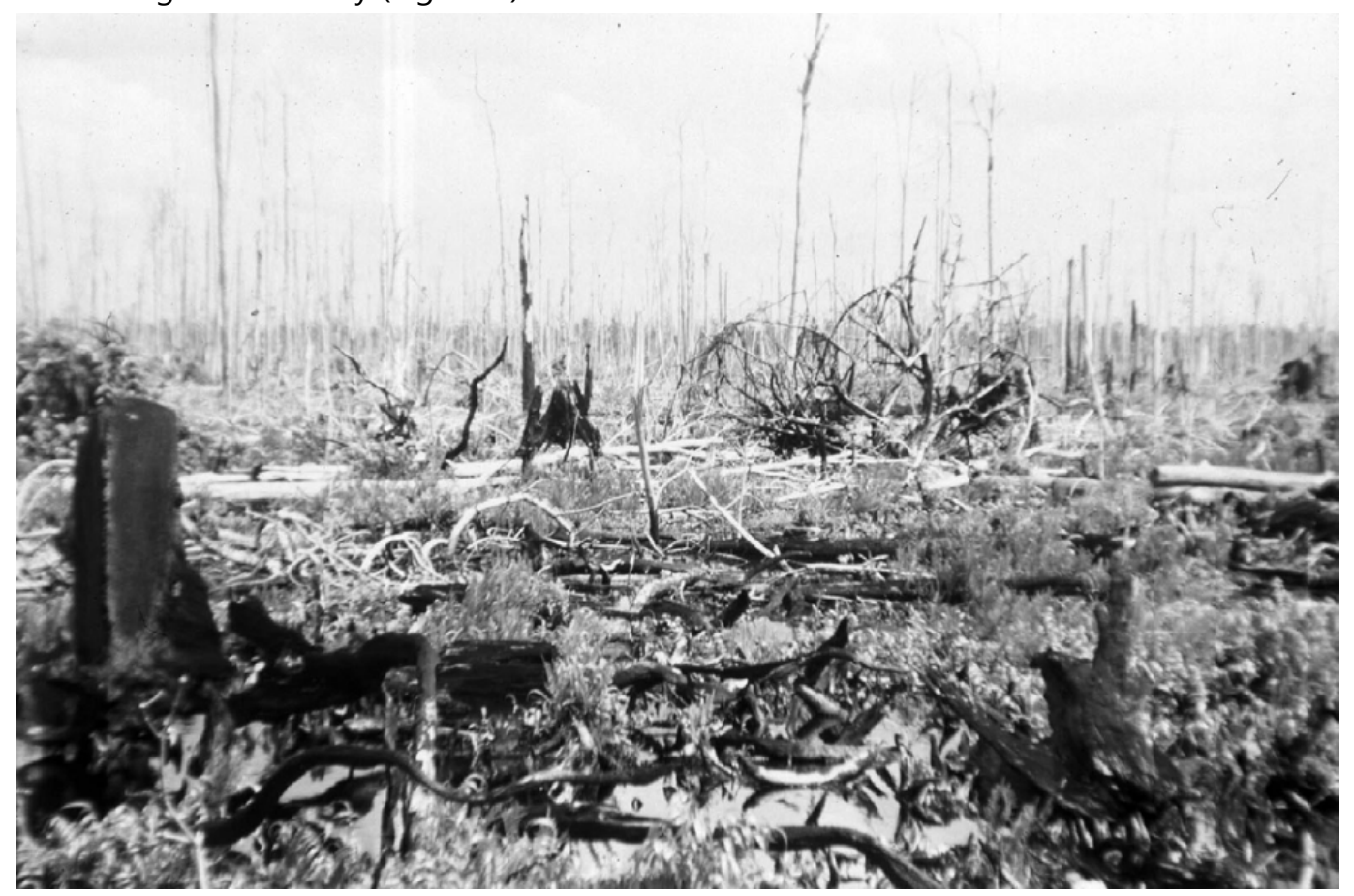

Figure 2. Burnt peat swamp forest in the study area

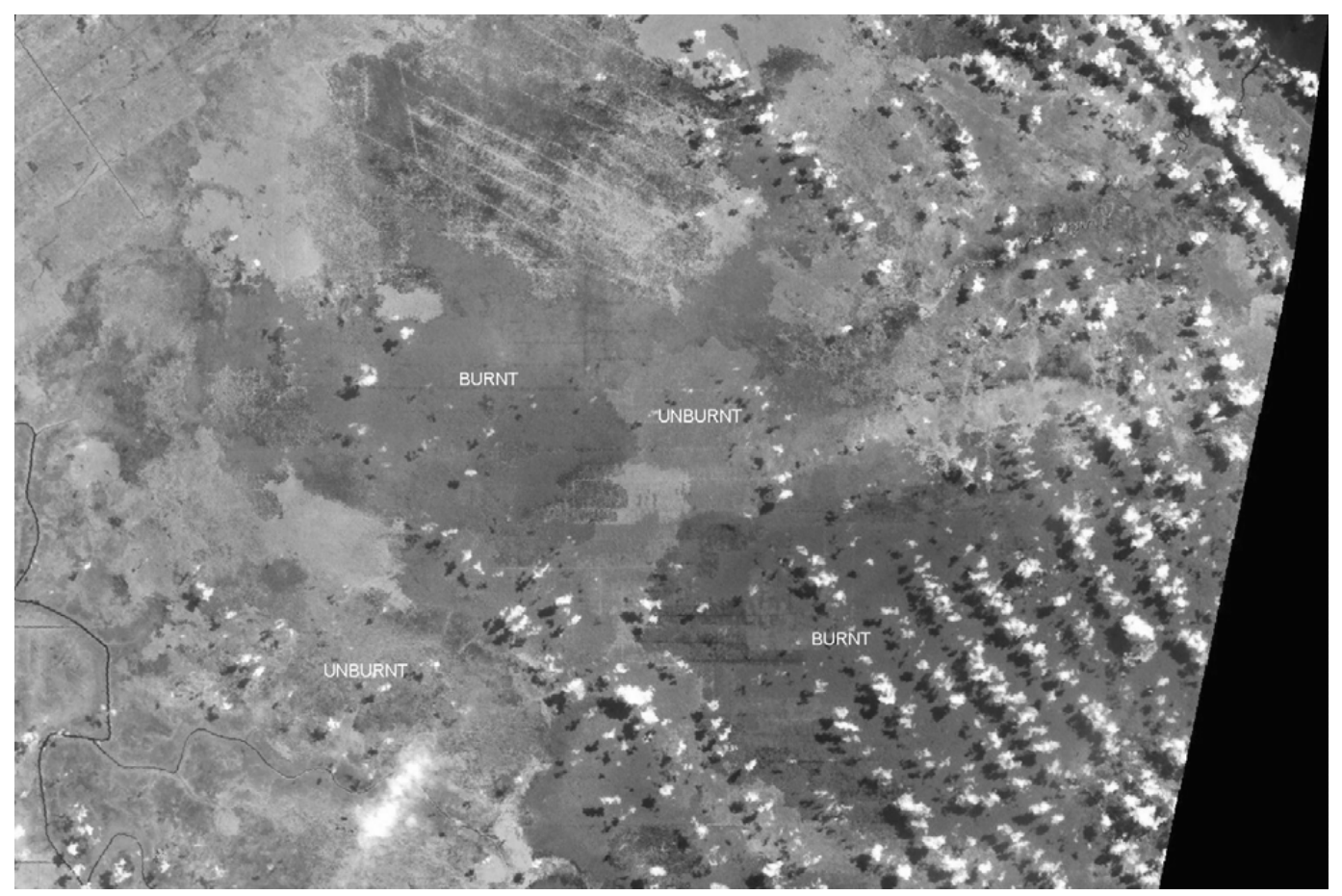

Figure 3. Landsat TM image of the study area 


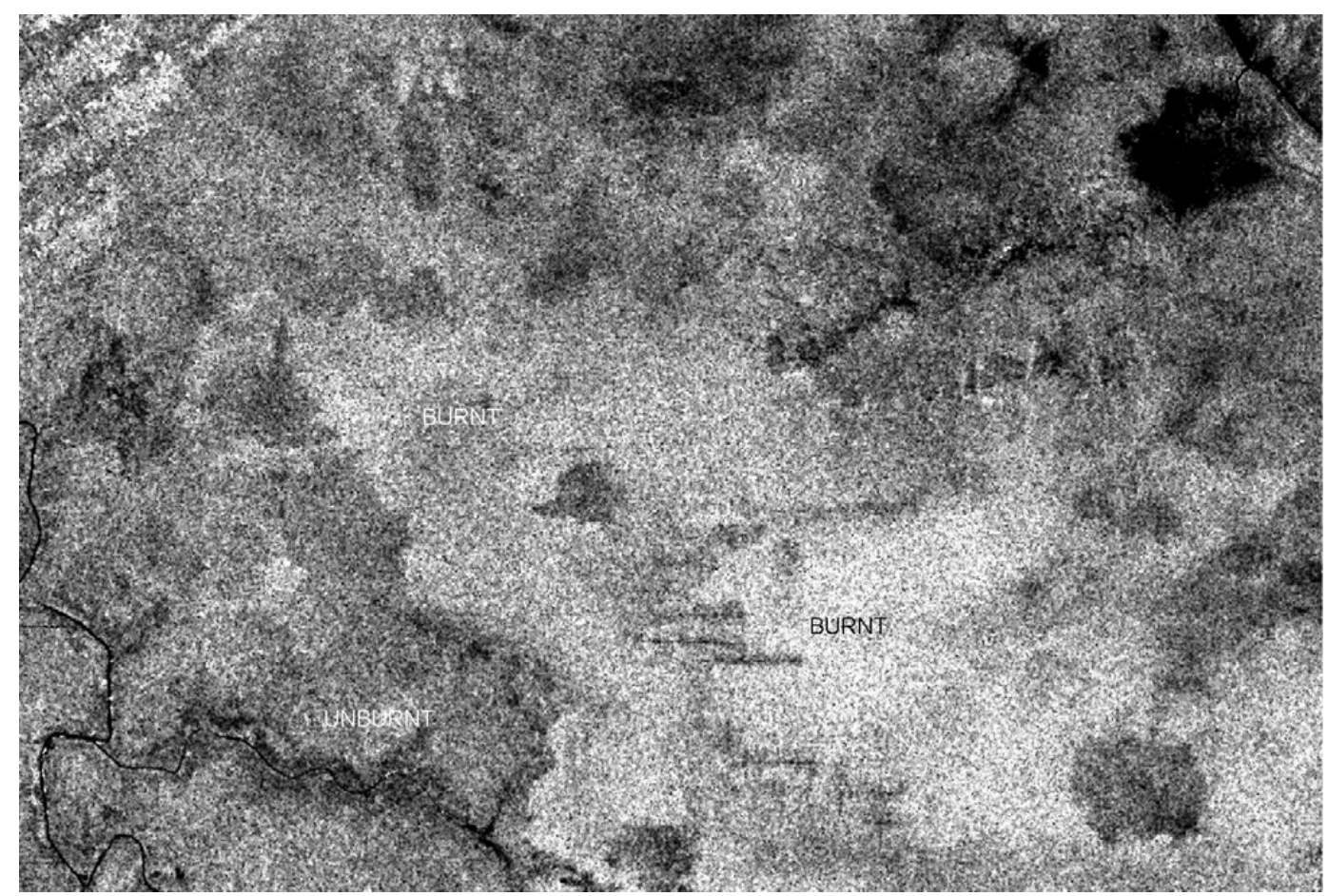

Figure 4. ERS-2 Radar image of the study area

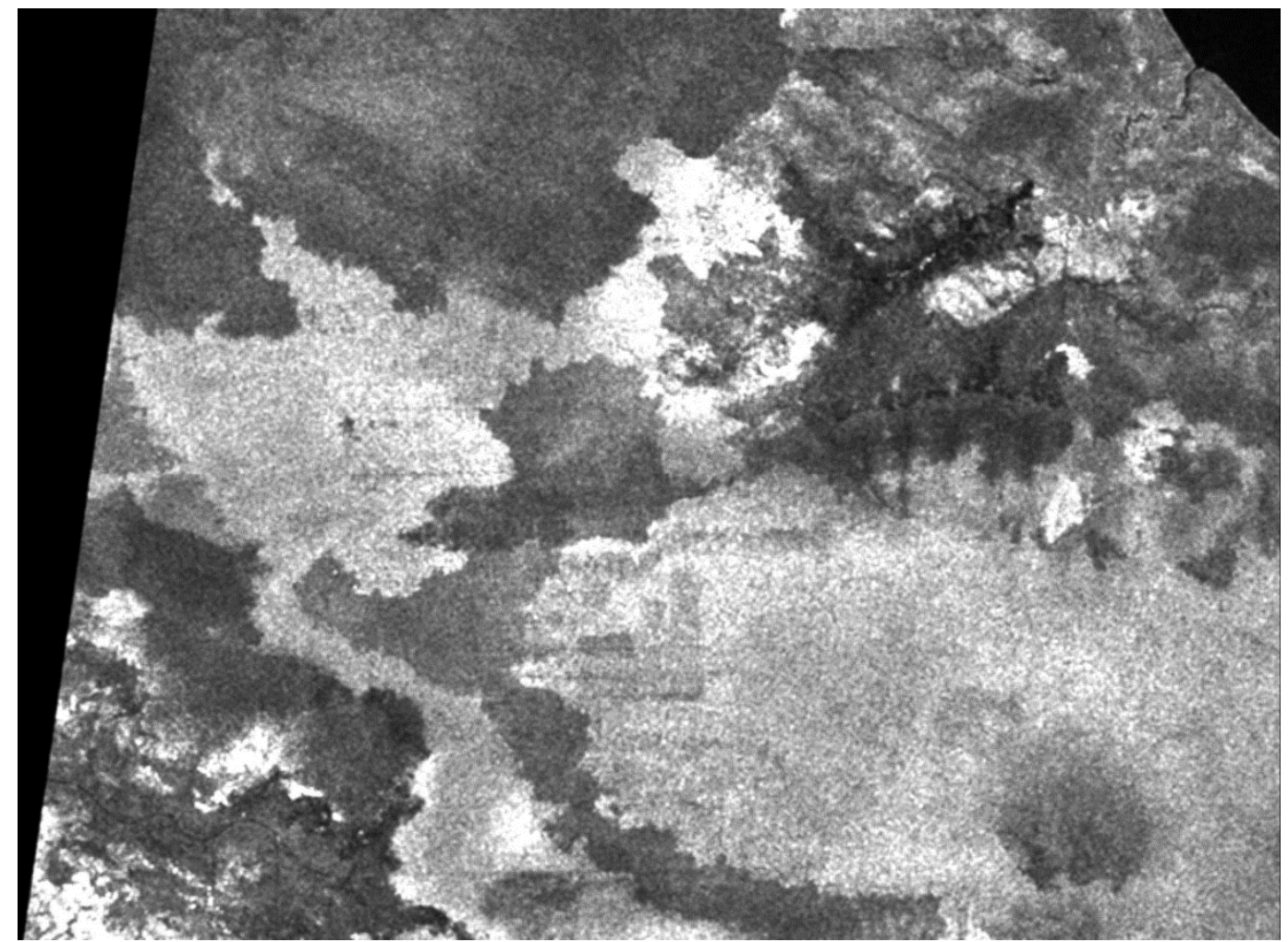

Figure 5. Pre-processed JERS SAR image shows the burnt area in a lighter tone

\section{LITERATURE CITED}

Goldammer J. G. and Valentin V. Furyaev. 1996. Fire in Ecosystem of Boreal Eurasia. Dordrecht/Boston/London : Kluwer Academic Publishers. Pages : 1-20 and 139-149 Stellingwerf D.A. and Yousif A. Hussin. 1997. Measurement and Estimation of Forest Stand Parameters Using Remote Sensing. Utrecht 